\title{
Repairing the Contingency Argument against Divine Simplicity
}

\author{
Matthew James Collier \\ Oriel College, Oxford
}

\begin{abstract}
According to classical theism, God is simple. However, contemporary objections to divine simplicity abound. One of those objections has received a lot of attention recently: the contingency objection. The objection is taken to pose a threat to God's freedom. Tomaszewski argues that the argument that supports the contingency objection, however, is invalid. Herein, I supply two valid versions of the argument; thus, the classical theist is required to defuse the argument.
\end{abstract}

\section{Introduction}

The doctrine of divine simplicity, roughly articulated, is that God is without metaphysical complexity: there are no spatial or temporal parts in God; nor in God are there distinct properties or attributes; there are no metaphysical distinctions to be found anywhere in The One. However, contemporary objections to divine simplicity abound. ${ }^{1}$ Some argue that divine simplicity is incompatible with the Trinity, ${ }^{2}$ others argue that the conjunction of the doctrine with the Incarnation is inconsistent, ${ }^{3}$ and others argue that divine simplicity is simply incoherent or leads to a denial of some central tenets of classical theism. ${ }^{4}$ The contingency problem, which I examine herein and which Oppy $(2014,99)$ and other philosophers take to be "the most apparently intractable problem for the doctrine of divine simplicity," falls under this last category: the objection is presented as an argument contra God's freedom..$^{5}$ If the argument is both sound, classical theists will be committed to waving goodbye either to divine simplicity or to divine freedom, since the argument's conclusion entails that everything that is, necessarily is; and, if everything that is, necessarily is, it is argued that God could not have willed otherwise. That God could not have willed otherwise, it is argued, threatens God's freedom. Accordingly, "modal Spinozism," as Leftow $(2015,48)$

\footnotetext{
${ }^{1}$ For an excellent introduction to divine simplicity, see Vallicella (2019).

2 See Moreland and Craig $(2003,586)$ and Stenberg $(2014,394)$.

3 See Hughes $(1989,253-64)$.

4 See Plantinga (1980, 46-61) and Gale (1991).

5 Specifically, the argument is an argument contra an account of God's freedom that requires the truth of (a version of) the principle of alternate possibilities (which, roughly, is the principle that $x$ freely performed $A$ only if $x$ could have not performed $A$ ). As we shall see below, Leftow (2015) provides good reason for thinking that this is the right sort of account of God's freedom. Herein, I shall not dispute the veracity of this account.
}

Journal of Analytic Theology, Vol. 9, Summer 2021 10.12978/jat.2021-9.120009021417

(C) 2021 Matthew James Collier • (C) 2021 Journal of Analytic Theology 
notes, "thus looms" if the argument holds water. Tomaszewski $(2019,276)$, however, thinks that the argument is invalid, and contends that a burden rests upon "those who pose such an argument to show that there is some version of it which is demonstrably valid." Herein I present two valid versions of the argument, and thus answer Tomaszewski's challenge. ${ }^{6}$

\section{The Charge of Invalidity}

Many presentations of the argument exist: some focus upon God's intentions, others God's actions, and others God's knowledge, to deliver the result that divine simplicity should be rejected. ${ }^{7}$ However, most presentations of the argument appear somewhat materially indistinguishable. Here, I follow Tomaszewski $(2019,277)$ in providing Mullins's (2016) articulation of the argument, given its perspicuity. Here is Mullins $(2016,138)$ :

On divine simplicity God's essence is identical to His existence. Also, God's one simple act is identical to His essence/existence. God's act of creation is identical to this one simple act, and so identical to God's essence/existence. God exists of absolute necessity. So His act of creation is of absolute necessity since it is identical to His essence/existence.

Its being contingent that God created the universe is an oft-cited feature of classical theism; indeed, many believe it to follow from divine freedom. For instance, Leftow $(2015,47-48)$ contends that if God lacks the ability to "will otherwise, nothing dependent entirely and solely on His will can be otherwise"; thus, if it is not in God's power to will otherwise, "there had to be a universe, and this universe." Thus, if the contingency argument is sound, we arrive at the following dilemma, articulated by O'Connor $(1999,406)$ : "either God is not metaphysically simple or His creating this world is somehow bound up with His very being." But, according to classical theists, God is simple and His creation of the world is contingent.

The argument is devastating, if sound. Tomaszewski (2019), however, thinks that the argument is invalid. Thus, Tomaszewski maintains, those in favour

\footnotetext{
6 The importance of the doctrine of divine simplicity in the history of philosophical theology cannot be overstated. Indeed, it enjoys central status in the works of medieval Christian philosophical theologians, like Augustine, Anselm and Aquinas, but also assumes a key position in many works of Islamic and Jewish theology and Greek philosophy. For example, Augustine remarks in The City of God XI: "There is then one sole Good, which is simple, and therefore unchangeable; and that is God" (Augustine (1984)); John of Damascus in On the Orthodox Faith 1.4 declares that God is "simple and uncompound" (John of Damascus (2007)); for Ibn Sīnā, in his Metaphysics of the Healing (Ilāhiyyāt 1.7.14), the "necessary existence" is simple, and all else is "composite" (Ibn Sīnā (2005)); in his The Guide of the Perplexed (1.52), Maimonides contends that "no multiplicity should be posited in Him" (Maimonides (1963)); and, Plotinus's Enneads (II.9.1.) speaks of "The First" as something "not of that compound nature which would make it dependent upon any constituent" (Plotinus (1962)). Thus, the validity of the contingency argument should be of significant interest to philosophical theologians.

${ }^{7}$ For examples of reasonably recent presentations of the argument, see O'Connor $(1999,406)$, Moreland and Craig $(2003,525)$, Pruss $(2008,151)$, Mullins $(2013,195-199)$, Oppy $(2014,99)$ and Leftow $(2015,47-49)$.
} 
of divine simplicity need neither amend the doctrine of divine simplicity nor deny one of the premisses of the argument in order to render the argument unsound. 8 Mullins's argument is formalised by Tomaszewski $(2019,277)$ as follows:

(1) Necessarily, God exists.

(2) God is identical to God's act of creation.

(3) Necessarily, God's act of creation exists.

To see where the argument miscarries, Tomaszewski $(2019,278)$ provides a formal rendering in quantified modal logic:

(where ' $G$ ' = God, and ' $C$ ' = God's act of creation)

(1) $\square \exists x(x=G)$

(2) $G=C$

(3) $\square \exists x(x=C)$

Tomaszewski notes that the argument is invalid due to Mullins's inadmissible use of the substitution principle - a principle which states that for any two terms, $x$ and $y$, if $x$ and $y$ are coextensional, then $x$ and $y$ are intersubstitutive, salva veritate. That is, for any true identity statement, $P$, any of its terms may be substituted for any other whilst preserving the truth of $P$. The use of the substitution principle is valid within extensional logics, but not (always) within intensional ones; modal logic, however, is an intensional logic. ${ }^{9}$ Thus, Tomaszewski contends, Mullins errs: within the scope of the necessity operator, the term God's act of creation is substituted for the term God, where the two terms are not intersubstitutable, salva veritate. That is, under the necessity operator, God's act of creation cannot be substituted for God whilst preserving the truth of the statement. But why is this so? Citing Quine $(1953$, ch8), Tomaszewski $(2019,278)$ reminds us that "modal contexts are referentially opaque," and so one cannot substitute willy-nilly one term for an entity to another term for the same entity within the scope of a modal operator whilst preserving the truth of the original statement. Here is an illustration of the invalidity of the substitution principle under modal logic, given the logic's intensional nature. Take the necessity statement:

(4) Necessarily, all my horses are odd-toed ungulates. ( $\square \forall x(H x \rightarrow O x))$

(4) is true. But this does not mean that we are permitted to substitute the term my horses for the term my animals, even though all my animals - in this world happen to be horses. Indeed, the following necessity statement is not entailed by (4):

\footnotetext{
8 For responses of this type, see Stump and Kretzman (1985), O'Connor (1999), Grant (2003; 2012), Pruss (2008) and Brower (2008). The most popular strategy in the literature seems to be to construe God's intentions as extrinsic rather than intrinsic.

9 The fact that modal logic is intensional does not entail that an appropriate semantic theory thereof must also be intensional. Indeed, possible worlds semantics provides modal logic with an extensional semantic theory: the modal operators are taken as quantifiers over worlds.
} 
(5) Necessarily, all my animals are odd-toed ungulates. ( $\square \forall x(A x \rightarrow$ $O x)$ )

Clearly, (5) is false (if the axiom ' $A \rightarrow \square A$ ' (modal Spinozism) is false, which seems so). It is possible, for instance, that I own some chickens - and this possibility, if it be so, is sufficient to render (5) false. Thus, I hope to have made clear, the substitution principle is invalid in modal logic.

With the falsity of the substitution principle under modal logic established, Tomaszewski highlights that, per impossibile, were Mullins's argument valid, it would target every Abrahamic religion that takes God to exist by necessity and to be The Creator. This is so, Tomaszewski $(2018,4)$ thinks, because the following argument is identical in form and symbolisation to Mullins's argument:

(Where ' $G$ ' = God and ' $T$ ' = The Creator)

(6) $\square \exists x(x=G)$

(7) $G=T$

(8) $\square \exists x(x=T)$

Tomaszweski $(2019,279)$ contends that the argument would be valid were (2) prefixed with a necessity operator:

$\left(2^{*}\right) \quad \square(G=C)^{10}$

However, as Tomaszweski (2019) notes, it is immediately obvious to classical theists why $\left(2^{*}\right)$ should be rejected. By taking it as necessary that God is identical with His act of creation (i.e. by affirming $\left(2^{*}\right)$ ) one begs the question against classical theists. Indeed, that it is contingent that God created the universe is what classical theists affirm - and the doctrine of simplicity, although entailing that God is necessarily identical with His act, does not entail that God create the universe, and thus does not entail that God is necessarily identical with God's act of creation (thus, $\left(2^{*}\right)$ should be rejected). That is, all that the doctrine entails is that God is necessarily identical with His act, but what that act is is not established by necessity from the doctrine. Thence, simply installing the assumptive premiss that necessarily God is identical with His act of creation will not convince the classical theist that divine simplicity entails that it is necessary that God created the universe. Thus, if the argument includes premise (2), then it is invalid; but if the argument includes premise $\left(2^{*}\right)$, then it begs the question against classical theists. ${ }^{11}$

\footnotetext{
${ }^{10}$ An anonymous reviewer contends that the type of necessity in $\left(2^{*}\right)$ is ambiguous, and asks: is the necessity logical or metaphysical? The reviewer thinks that either option does not work for the argument. I agree there are problems with including $\left(2^{*}\right)$ : indeed, neither I nor Tomaszweski nor any classical theist wish to defend including $\left(2^{*}\right)$ in the argument.

${ }^{11}$ Here one might think that if identity is necessary, and $G$ and $C$ are rigid designators such that they pick out God in every world in which He exists (which is all worlds), then we get ' $G=C \rightarrow$ $\square(G=C)^{\prime}$. But, if this is so, the premiss $\left(2^{*}\right)$, ' $\square(G=C)$ ', can simply be installed into the argument, contra Tomaszewski. However, as Tomaszewski argues, for this to be true (that is, for $C$ to pick out God in every world in which He exists), God would have to have the intention to create the universe in every world; and this is something that classical theists deny. Tomaszewski does not deny the necessity of identity, but he does deny that classical theists should take $C$ as a rigid designator (See Tomaszewski $(2019,280-281))$.
} 
Moreover, if one thought that the inclusion of the premiss:

$$
\square \exists x(x=G \& S(x))
$$

Where 'S' expresses the property of simplicity, as follows:

$$
\mathrm{S} \mathrm{x}=\mathrm{S} \text { is simple }
$$

committed classical theists to (2*), Tomaszweski (2019) says think again. Tomaszewski thinks that all that (9) commits classical theists to is the claim that God is identical with His act - but it does not entail that necessarily that act is the act of creation; indeed, it does not entail $(2 *) .{ }^{12}$

I take Tomaszewski's objection against Mullins's version of the argument to be decisive. ${ }^{13}$ However, one may be suspicious that Tomaszewski has not formalised the best version of the argument. Certainly, Mullins's rendition is perspicuous, but it seems that the other rendition of the argument found in Tomaszewski (2019) - i.e. one provided by Leftow (2015) (who does not support the argument) - is quite distinct. Indeed, Leftow's rendition makes explicit mention of God's intention, and revising the nature of God's intention is precisely the strategy to block the argument's conclusion wherewith the literature is suffused. ${ }^{14}$ Here is Leftow's $(2015,48)$ informal rendition of the argument:

On DDS, nothing in God is really distinct from anything else in Him. If so, then everything wholly within God - everything intrinsic to God - is identical with everything else in God. Suppose, then, that God's intentions are wholly within God. If they are, it follows that they are all identical: God has just one intention. Further, God's intention $=$ His essence. God has His essence necessarily. So it seems to follow that He has His actual intention necessarily. But then it seems that He necessarily wills just what He does: that He could not have willed otherwise.

Here is my formalised version of Leftow's argument (I include some premisses that I take to be tacit in Leftow's informal rendition, and also give God's intending to create the universe as an example of God's actual intention):

(10) God is simple. (Assumption)

(11) If (10), then anything intrinsic to God is identical to everything else intrinsic to God. (By simplicity)

\footnotetext{
${ }^{12}$ An anonymous reviewer notes that (9) does not commit theists to the view that God is identical with His act, and also notes that this is especially unclear if we if we are not told what this act even is. I agree here. And so, (9)'s problems are greater than Tomaszewski thinks, and thus worse for the classical theist who thinks that installing (9) into the argument solves the problem. 13 Tomaszewski $(2019,280-283)$ also considers various other ways to repair the argument: he considers a strategy of appealing to rigid designation and a strategy of applying Leibniz's Law. Both strategies, he argues, fail. I do not contend otherwise.

${ }^{14}$ O'Connor (1999) is a good example of an account of the extrinsicality of God's contingent intentions. See Leftow (2015) for an objection thereto concerning divine freedom. See Stump and Kretzmann (1985) for a discussion of extrinsic and intrinsic properties in relation to God. Grant (2003) also argues that 'God's creating the universe' can be construed in extrinsic terms, and Grant (2012) develops a similar argument, but focussing on the extrinsicality of God's knowledge.
} 
(12) Anything intrinsic to God is identical to everything else intrinsic to God. (10,11 MP)

(13) God's intentions are intrinsic to God. (Assumption)

(14) God's intentions are identical to each other. $(12,13)$

(15) God has one intention. (14, by identity)

(16) God's essence is intrinsic to God. (Assumption)

(17) God's intention is identical to His essence. $(12,13,16)$

(18) Necessarily, God has His essence. (Assumption)

(19) Necessarily, God has His intention. (17, 18 by substitution)

(20) God's intending that He create the universe is identical to His intention. (assumption)

(21) Necessarily, God intended that He create the universe. $(19,20)$

(22) If (21), then God could not have intended otherwise than intend to create the universe. (By necessity)

(23) Therefore, God could not have done otherwise than intend to create the universe. (21, $22 \mathrm{MP})$

This argument is much more complex, and focusses upon God's intentions. However, Leftow's, like Mullins's, argument is invalid. Although it is true that God did intend to create the universe, and it is true that God's intention is identical to His essence (17), and His essence is necessary (18), and so His intention is necessary (19), it does not follow that necessarily God's intention is to create the universe (that is, (21) does not follow). ${ }^{15}$ Thus, Leftow (on behalf of the supporter of the contingency argument) inadmissibly avails himself of the substitution principle: within the scope of the necessity operator, God's intending that He create the universe is substituted for God has His intention, when the two terms are not intersubstitutable salva veritate. Tomaszewski's argument for the invalidity of Mullins's version can thus be extended to Leftow's rendition of the argument.

I hope now to have vindicated Tomaszewski from the potential accusation of his taking just one - perhaps poor - rendering of the argument, noting its invalidity and then generalizing that invalidity to all the argument's renderings. Indeed, as I have shown, Leftow's $(2015,48)$ argument (which he does not support) is also invalid. But, all is not lost for the argument: I believe that a valid version can be provided.

\section{Validating the Argument}

I now present two valid versions of the argument. Each of the following two versions constitute an argument for the falsity of at least one of the following claims: (a) that God is simple, (b) that God's willing to create the universe is intrinsic to God, and (c) that contingently, God willed to create the universe. ${ }^{16}$ Let us take it as given that the classical theist denies neither (a) nor (c); thus, the battle

\footnotetext{
15 An anonymous reviewer contends that this step is a 'gross confusion'. I agree that the step is inadmissible. But, it is interesting that when versions of the argument are presented informally, the confusion does not seem so obvious. This is partly why formalising versions of the argument is of such interest.

${ }^{16}$ I thank an anonymous reviewer for helping me to think more clearly about what the argument amounts to.
} 
ground lies in the legitimacy of rejecting (b). And, this is just the result we want for the dialectic, since we want a valid version of the argument which is relevant to the common move made in the literature to defuse that argument, namely denying (b). Specifically, the argument versions below each take the form of a reductio ad absurdum: the conjunction of (a), (b) and (c) entails a contradiction. For someone who believes (b) and (c) to be unobjectionable, (a) must go. For the classical theist, who believes (a) and (c) to be unobjectionable, (b) must go. The following versions of the argument, then, allow the dialectic in the literature to not merely be like a scuffle over the colour of the shoes of a fictitious chimera, but to concern the soundness of a valid and formidable argument. Here is the first version: ${ }^{17}$

(24) Necessarily, God is simple. (Assumption)

(25) If (24), then if God is F, and F is intrinsic, then necessarily, God is F.

(26) If God is F, and F is intrinsic, then necessarily, God is F. $(24,25, \mathrm{MP})$

(27) Contingently, God willed to create the universe. (Assumption)

(28) God willed to create the universe, and willing to create the universe is intrinsic to God. (Assumption)

(29) Necessarily, God willed to create the universe. (26, 28, MP)

(30) If necessarily, $\mathrm{P}$, then it is not possible that not-P. (Assumption)

(31) It is not possible that it is not the case that God willed to create the universe. $(29,30, \mathrm{MP})$

(32) If contingently, $\mathrm{P}$, then it is possible that not-P. (Assumption)

(33) It is possible that it is not the case that God willed to create the universe. $(27,32, \mathrm{MP})$

(34) Therefore, it is not possible that it is not the case that God willed to create the universe and it is possible that it is not the case that God willed to create the universe. (31, 33, conjunction-introduction)

This argument is valid. Here is why. (24) is a given, given the terms of the debate. (25) is an expression of what (24) entails: i.e., that there are no accidental (i.e. contingent) intrinsic attributes of God. ${ }^{18}$ To see that the principle if God is F, and F is intrinsic, then necessarily, God is $F$ follows from the doctrine of simplicity, consider two worlds: $w$, wherein God wills to endow a universe with $n$ atoms (where $n<10$ ), and $u$, wherein God wills to endow a universe with $m$ atoms (where $m>10$ ). If we assume that God's will to endow a universe with atoms is intrinsic to God, then there will be an intrinsic difference in God between God in $w$ and God in $u$. If there is such an intrinsic difference in God across possible worlds, then God will have certain intrinsic properties in some possible worlds and others in others - and this violates divine simplicity. Thus, God must only possess essential (i.e. necessary) intrinsic attributes. So, we have (25). ${ }^{19}$ (26) follows by modus ponens

\footnotetext{
${ }_{17}$ Pruss's $(2008,151)$ version of the argument is somewhat similar to my two versions. So is Oppy's $(2014,99-100)$.

${ }^{18}$ Here I speak of 'attributes' and not of 'properties' to avoid ontological confusion, and to avoid commitment to an ontology of the divine attributes.

${ }^{19}$ Over email, Tien-Chun Lo has suggested another way to support (25). I quote Tien-Chun Lo at length:
}

It seems very plausible to me that God's essence is intrinsically the same in all worlds. Now in $w$, God's essence is identical to the property of willing a universe with $n$ atoms; 
from (24) and (25). (27) is a tenet of classical theism. (28) seems reasonable: God's will seems intrinsic to God (although many deny this; but, my aim here is not to defend the soundness of the argument - it is to supply a valid version). (29) follows by modus ponens from (26) and (28). (30) is a statement of what 'necessarily, P' entails. (31) follows by modus ponens from (29) and (30). (32) is a statement of what 'contingently, $\mathrm{P}$ ' entails. (33) follows by modus ponens from (27) and (32). And, the contradiction of the form ' $\neg A \& A$ ' (where ' $A$ ' is a possibility statement) imbedded in (34) follows by conjunction-introduction from (31) and (33). So, we have a valid version of the argument, and thus classical theists must reject one of its premisses. The obvious premiss to reject is (28); but it is not my place to do that here - my place is just to supply a valid version of the argument, that includes a premiss that some classical theists have deemed false, namely, (28). ${ }^{20}$

Here is another version:

(35) Necessarily, God is simple. (Assumption)

(36) If (35), then necessarily if God is F, and F is intrinsic, God is necessarily $F$.

(37) Necessarily if God is F, and F is intrinsic, God is necessarily F. $(35,36$, $\mathrm{MP})$

(38) God's possibly creating a world $w$, wherein a universe has $n$ atoms (where $n<10$ ), presents a possible intrinsic difference in God from His possibly creating a world $u$, wherein a universe has $m$ atoms (where $m>10$ ). (Assumption)

(39) If (38), then necessarily, if God is F, and F is intrinsic, God is necessarily $F$ is false.

(40) Necessarily, if God is $F$, and $F$ is intrinsic, God is necessarily $F$ is false. $(38,39 \mathrm{MP})$

in $u$, God's essence is identical to the property of willing a universe with $m$ atoms. If the properties of willing a universe with $\mathrm{m} / \mathrm{n}$ atoms are intrinsically different (which seems quite plausible too), then God's essence will vary intrinsically from world to world. This contradicts the principle that God's essence is intrinsically the same in all worlds.

${ }^{20} \mathrm{~A}$ reviewer notes that premiss (28) may be question-begging against classical theists, depending upon the account of intrinsicality in use. Indeed, if the Lewis-Langton account is used, where an attribute is intrinsic, roughly, iff it is independent of accompaniment by other contingent things, then assuming 'necessarily, if God wills to create a universe, then that universe exists' is true and the universe is contingent, God's willing to create the universe is not intrinsic to God (contra (28)).

Herein, I understand intrinsicality in (roughly) the following way: an intrinsic attribute of $x$ is something that $x$ has purely by virtue of the way that $x$ is itself. God has His will to create the universe by virtue of the way He is, and not by virtue of the way anything outside Him is. This corresponds to one of Lewis's (1983: 197) characterisations of intrinsicality: $x$ has $F$ intrinsically iff $x$ has $F$ in virtue of the way $x$ is itself. An account that is not question-begging against classical theists is Ellis (1991). For Ellis, if $F$ is intrinsic to $x$, then $F$ is intrinsic to $x$ not by virtue of any forces outside $x$ acting upon $x$. God has His will to create the universe not by virtue of anything outside Him acting upon Him. Of course, developing a full-blown account of intrinsically lies outside the scope of this paper, but I have noted that there are accounts of intrinsicality - which seem consistent with our pre-theoretical understanding of the notion - that do not render (28) question-begging. 
(41) Necessarily, if God is F, and F is intrinsic, God is necessarily F is true and necessarily, if God is $F$, and $F$ is intrinsic, God is necessarily $F$ is false. $(37,40 \text { conjunction-introduction })^{21}$

This argument is valid. Here is why. (35) is a given, given the terms of the debate. (36)'s plausibility has been stated above, with the exception that I have prefixed the consequent with 'necessarily' - and this should not concern us: if God is simple, the 'necessarily' prefixed consequent still follows. (37) follows by modus ponens from (35) and (36). (38) seems reasonable (again, this is where classical theists push back; but, in this paper, it is not my task to argue that (38) is false). (39) seems right: if God's possibly creating a world wherein a universe has $n$ atoms presents a possible intrinsic difference in God from His possibly creating a world wherein a universe has $m$ atoms, then it is not the case that: necessarily, if God creates a world wherein a universe has $n$ atoms, then it is necessary that God creates a world wherein a universe has $n$ atoms, and nor is the case that: necessarily, if God creates a world wherein a universe has $m$ atoms, then it is necessary that God creates a world wherein a universe has $m$ atoms. (40) follows by modus ponens from (38) and (39). And, the contradiction of the form ' $\neg A \& A$ ' imbedded in (41) follows by conjunction-introduction from (37) and (40). So, we have a valid version of the argument, and thus classical theists must reject one of its premisses. The obvious premiss to reject is (38); but it is not my place to do that here - my place is just to supply a valid version of the argument, that includes a premiss that some classical theists have deemed false, namely, (38).

And so, presenting the argument in the form of a reductio ad impossibilem, like my two versions of the argument above, renders the argument valid. Thus, contra Tomaszweski, classical theists are required to defuse the argument.

Acknowledgements: I would like to thank Gonzalo Rodriguez-Pereyra, Robert Koons, Ben Koons, Martin Pickup, and Tien-Chun Lo for comments on earlier drafts of this paper.

\section{References}

Augustine. 1984. Concerning the City of God Against the Pagans. Trans. H. Bettenson. London: Penguin Books.

Brower J. E. 2008. "Making Sense of Divine Simplicity”. Faith and Philosophy 25(1): 3-30.

URL: https://place.asburyseminary.edu/faithandphilosophy/vol25/iss1/1/

Ellis B. 1991. "Scientific Essentialism". Paper presented to the 1991 conference of the Australasian Association for the History and Philosophy of Science.

\footnotetext{
${ }^{21}$ The reader will note that I have prefixed the conditional 'if God is F, and F is intrinsic, God is necessarily $F^{\prime}$ ' with 'necessarily'. This is due to the nature of the argument; I do not wish to talk about the falsity of a material conditional. I thank Robert Koons for discussing this point with me.
} 
Gale R. 1991. On the Nature and Existence of God. Cambridge: Cambridge University Press.

Grant W. 2003. "Aquinas, Divine Simplicity, and Divine Freedom". Proceedings of American Catholic Philosophical Association 77:129-44. URL: https://www.pdcnet.org/collection/show?id=acpaproc_2003_0077_0000 _0129_0144\&file_type=pdf

. 2012. "Divine Simplicity, Contingent Truths, and Extrinsic Models of Divine Knowing". Faith and Philosophy 29(3): 254-274. URL: https://place.asburyseminary.edu/faithandphilosophy/vol29/iss3/2/

Hughes C. 1989. A Complex Theory of a Simple God. Ithaca, NY: Cornell University Press.

Ibn Sīnā. 2005. The Metaphysics of the Healing. Trans. M. E. Marmura (ed.). Provo: Brigham Young University Press.

John of Damascus. 2007. “On the Orthodox Faith”. In: P. Schaff and H. Wace (eds.), Nicene and Post-Nicene Fathers, Second Series: Hilary of Poitiers, John of Damascus, vol.9. New York: Cosimo Classics.

Leftow B. 2015. "Divine Simplicity and Divine Freedom". Proceedings of American Catholic Philosophical Association 89:45-56. URL: https://www.pdcnet.org/scholarpdf/show?id=acpaproc_2015_0089_004 5_0056\&pdfname=acpaproc_2015_0089_0045_0056.pdf\&file_type=pdf

Lewis D. 1983. “Extrinsic Properties”. Philosophical Studies, 44: 197-200.

Maimonides. 1963. The Guide of the Perplexed. Trans. S. Pines. Chicago: University of Chicago Press.

Moreland J. and Craig W. 2003. Philosophical Foundations for a Christian Worldview. Downers Grove, IL: InterVarsity Press.

Mullins R. 2013. "Simply Impossible: A Case Against Divine Simplicity". Journal of Reformed Theology 7:181-203. URL: https://brill.com/view/journals/jrt/7/2/articlep181_4.xml?language $=$ en 2016. The End of the Timeless God. Oxford: Oxford University Press.

O'Connor T. 1999. "Simplicity and Creation". Faith and Philosophy 16: 405-12. URL: https://place.asburyseminary.edu/faithandphilosophy/vol16/iss3/8/

Oppy G. 2014. Describing Gods: An Investigation of Divine Attributes. Cambridge: Cambridge University Press. 
Plantinga A. 1980. Does God Have a Nature? Milwaukee, WI: Marquette University Press.

Plotinus. 1962. Enneads. 3rd ed. Trans. S. MacKenna. Rev. B. S. Page. New York: Pantheon Books.

Pruss A.R. 2008. "On Two Problems of Divine Simplicity". Oxford Studies in Philosophy of Religion 1: 150-167.

Quine W.V.O. 1953. "Reference and Modality". In his From a Logical Point of View. Cambridge, MA: Harvard University Press. 139-159.

Stenberg J. 2014. "Divine Properties, Parts, and Parity". International Journal of Philosophy and Theology 75(5): 388-405. URL: https://www.tandfonline.com/doi/abs/10.1080/21692327.2015.10311 60

Stump E. and Kretzmann N. 1985. "Absolute Simplicity". Faith and Philosophy 2: 353-82. URL: https://place.asburyseminary.edu/faithandphilosophy/vol2/iss4/3/

Tomaszewski C. 2019. "Collapsing the Modal Collapse Argument: On an Invalid Argument Against Divine Simplicity". Analysis 79(2): 275-284. URL: https://academic.oup.com/analysis/article/79/2/275/5062919

Vallicella W. F. 2019. "Divine Simplicity". Stanford Encylopedia of Philosophy. E. N. Zalta (ed.). Available at: <https://plato.stanford.edu/entries/divinesimplicity/> [Accessed 18 May 2020]. 